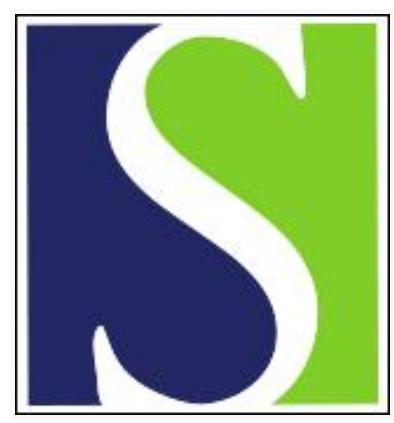

Scand J Work Environ Health 2020;46(1):1-4

https://doi.org/10.5271/sjweh.3870

Published online: 29 Nov 2019, Issue date: 01 Jan 2020

Trends and success stories in research on occupational and environmental health

by Härmä $M$

Affiliation: Finnish Institute for Occupational Health, Helsinki, Finland. Email: mikko.harma@ttl.fi

Refers to the following texts of the Journal: 2016;42(3):181-191

2015;41(5):491-503 2015;41(2):153-163 2015;41(2):164-174

2015;41(1):54-64 2014;40(2):109-132 2014;40(1):5-18

2014;40(2):195-202 2010;36(2):81-84 1975;1(1):1-14

1977;3(3):144-153 1992;18(1):1-9 2007;33(4):245-251

1993;19(5):297-312 2007;33(1):1-3 1997;23(4):243-256

1997;23(4):311-316 1999;25(2):85-99 1999;25(6):465-469

2006;32(6):413-419 2006;32(6):431-442 2006;32(6):443-462

2016;42(3):177-180 2016;42(5):359-370 2017;43(1):24-33

2017;43(1):86-94 2017;43(1):59-67 2017;43(4):294-306

2017;43(6):526-539 2018;44(1):3-15 2018;44(2):134-146

2018;44(3):229-238 2018;44(3):239-250 2019;45(3):215-216

2019;45(5):527-528

The following article refers to this text: 2021;47(2):91-93

Key terms: occupational and environmental health; occupational health; research; trend

This article in PubMed: www.ncbi.nlm.nih.gov/pubmed/31781774 


\section{Trends and success stories in research on occupational and environmental health}

The headline in a main Finnish newspaper on 16 November announced: "Trust and interest for published science has increased in Finland". I would have hypothesized that evidence-based knowledge was losing the game against the rush of non-scientific and commercial information-but I was wrong. A 3-year follow-up survey among the Finland population was clear on this. Could the growth in electronic and social media information actually be causing people to search for knowledge based on scientific facts?

Forty-five years have passed since the publication of the first issue of the Scandinavian Journal of Work, Environment \& Health (SJWEH) in January 1975. The Journal is unique due to its non-profit profile in a sea of large, commercial publishing house journals. With a current impact factor of 3.491, SJWEH is recognized for its high quality and interesting content. The main aim of the Journal has always been to promote good and impactful research in the field of occupational and environmental health and safety. The Journal makes a difference by providing its readership with innovative topics, systematic reviews on existing knowledge, and papers using advanced research methods. Over the years, the scientific focus areas of occupational research, research methods, and academic publishing have undergone major changes. In fact, the Journal's transformation over more than four decades can be used as a good example of how occupational research and publishing policy has adapted to the new trends in scientific knowledge and information technology.

Well-known professor of epidemiology and specialist in occupational medicine, Sven Hernberg was the first Editor-in-Chief (EC) of the Journal. SJWEH was based on earlier ancestor journals (1), but in practice Sven had to start from scratch both scientifically and economically. Together with Sven, Markku Nurminen, epidemiologist and biostatistician, and native English-speaking copy editor Georgianna Oja belonged to the first editing team. SJWEH was launched as the joint activity of the Swedish, Danish, Norwegian and Finnish national research institutes. Even though the Journal's main focus in the beginning was on occupational medicine, toxicology and epidemiology, Sven wanted to support some developing fields of research at the time such as research of musculoskeletal disorders and biological monitoring. He was interested in preventive actions and the initialization of long follow-up studies in occupational medicine (2). The very first SJWEH paper was a review on neurophysiological methods (3). The first paper on psychosocial factors, published by Theorell in 1977, was on the association of psychosocial factors in concrete work with myocardial infarction (4).

Based on the 20 "citation classics" (defined as publications with $\geq 100$ citations) of the five most distinguished occupational medicine journals (5), citation classics dealing with toxicology were published in each decade during those times. However, well-cited papers on solvents appeared only during the 1970s and 1980s and were instrumental in the phasing out of organic solvents-based paints. Citations classics on work-related musculoskeletal disorders emerged in the 1980s and gained in popularity in the later decades (5). Compared to other occupational health journals, SJWEH had the second highest number of citation classics during the early decades of its existence. With $>900$ citations in Scopus, a 1993 paper on the association of psychosocial factors with musculoskeletal diseases by Bongers (6) was among one of the most cited.

I took up the position of Assistant EC after Markku in 1994. During the next few years, Sven and I updated our editing processes. A new electronic publishing system was created in 1998 , making it possible to shift to a joint co-editor model. Several new Associate Editors (AE) were brought on board, increasing the expertise of the Journal significantly and making the editing process more interactive. Eira Viikari-Juntura, Petter Kristensen, Per Malmberg, Thomas Schneider, Lars Hagmar, Michiel Kompier, Kjell Larson, and Gunnar Aronson joined the Journal in the first wave starting 1999-2000. When Sven retired at the end of 1999, I became the EC sharing, 
however, the key management and decision-making together with Eira, who took on the role of Assistant EC in 2000. As a supplement to the paper version, an electronic version of the Journal was launched in 2001.

In his last editorial before retiring (7), Sven emphasized the significance of the need to shift the focus to new areas of research. While traditional occupational diseases were - and still are - a burden in many countries, he highlighted that the main roadblock in their remedy is not additional research but implementation of already existing knowledge (7). Taking the lead, we started to focus on new areas where existing knowledge was not great, especially psychosocial issues and musculoskeletal disorders, while maintaining a strong presence in epidemiological and clinical research on occupational epidemiology.

During the 1990s, we had already started to publish editorials and reviews in all issues of the Journal. Several of the latter became citation classics, for example those on exposure assessment and musculoskeletal issues by Burdorf (8) and Burdorf \& Sorock (9) and a review on shift work and cardiovascular diseases by Bøggild \& Knutsson (10). We also published consensus reports on key issues like the new Helsinki criteria for diagnosis and attribution on asbestos, asbestosis and cancer (11), extensively cited later, up to its update a few years ago (12), and special issues on growing research areas like work-related stress: health-risks, mechanisms and countermeasures (13) and shift work and health (14). These special issues included several reviews that also became citation classics. The review on psychosocial factors and mental health by Stansfeld \& Candy (15), in particular, has been cited $>900$ times based on Scopus, as well as a review on work stress and coronary heart disease by Kivimäki and colleagues (16) (>500 times).

During the 2000s, in addition to relevance, emphasis was placed on shortening article processing time and improving accessibility of the Journal (17). Some new AE were brought onto the team to improve the Journal's expertise in new key research areas. Being among the key scientists publishing and actively reviewing for the Journal, Alex Burdorf, Bengt Järvholm, Göran Kecklund, Jos Verbeek, Hannu Norppa, Antero Aitio, and Jens Peter Bonde all started as new AE. To speed up the flow of manuscripts and improve accessibility, we shifted to a full electronic submission and review process and launched the "online first" policy, making all papers open access until their publication in the print version. These efforts, along with higher quality submissions increased citations and raised the impact factor. When Georgianna retired in 2009, Lisa O'Donoqhue-Lindy started as the new Managing Editor. In addition to being responsible for copy editing, Lisa promoted the electronic and open access services of the Journal and has always been very active in its development and benchmarking against other journals.

From 2008 to today, the impact factor of the Journal has doubled, and currently we hold a close second among all journals in the field of occupational and environmental health. During the same period, the number of submitted papers has doubled allowing us to be more selective and publish only the best research, which is depicted in the current acceptance rate of $15 \%$. Since the beginning of 2012, the non-profit Nordic Association of Occupational Safety and Health (NOROSH) has published the Journal. As earlier, the Nordic research institutes play a key role as founding members of NOROSH.

Papers published on epidemiology, especially those associated with psychosocial factors (18-21), long working hours and shift work (22-26), as well as papers on musculoskeletal disorders, physical activity, work careers and return-to-work (27-31) performed better than average with respect to citations. However, papers introducing or using new methodologies (32-34) have gained much attention, too.

The last two years have been historical for the Journal for several reasons. Sven sadly passed away (2). When Eira retired as Assistant EC in 2018, Alex Burdorf, Head of the Department of Public Health at Erasmus University Medical Centre joined me as co-EC. And when I decided to step down at end of 2019, Reiner Rugulies, Professor of Psychosocial Issues and Mental Health at the Danish National Research Centre for the Working Environment became EC alongside Lex, after earlier having been an AE. I will continue as an AE for the topics of shift work and working hours. In the meantime, several new AE have joined the team: Karin Broberg, Håkan Wallin, David Lombardi, Karl-Christian Nordby, Carel Hulshof, Susanne Svendsen, Hermann Burr and Vivi Schlünssen several years ago, and, more recently, Annina Ropponen, Henrik Kolstad, Cécile Boot, and Paul Kuijer. 
In the future, as the editorial team has pointed out, the Journal will place greater emphasis on scientific quality and innovative research topics and methods (35). Staying ahead of the Open Science Movement, we recently decided to take the important step towards becoming a fully fledged open access journal. Starting in 2020, open access will be by opt-out only and in 2022, we will publish $100 \%$ unlocked content. Thus the Scandinavian Journal of Work, Environment \& Health will remain a relevant, high-quality, non-profit scientific journal that is unique in many ways.

\section{References}

1. Smith DR. A history of the Scandinavian Journal of Work, Environment \& Health. Scand J Work Environ Health. 2016;42(3):177-80. https://www.sjweh.fi/show_abstract.php?abstract_id=3558

2. Rantanen J. Professor Sven Hernberg, 1934-. Scand J Work Environ Health. ;45(3):527-8. https://doi.org/10.5271/sjweh.3849

3. Seppäläinen AM. Applications of neurophysiological methods in occupational medicine. A review. Scand J Work Environ Health. 1975;1(1):1-14. https://doi.org/10.5271/sjweh.2865

4. Theorell T, Olsson A, Engholm G. Concrete work and myocardial infarction. Scand J Work Environ Health. 1977;3(3):144-53. https:// doi.org/10.5271/sjweh.2779

5. Gehanno JF, Takahashi K, Darmoni S, Weber J. Citation classics in occupational medicine journals. Scand J Work Environ Health. 2007;33(4):245-51. https://doi.org/10.5271/sjweh.1139

6. Bongers PM, de Winter CR, Kompier MA, Hildebrandt VH. Psychosocial factors at work and musculoskeletal disease. Scand J Work Environ Health. 1993;19(5):297-312. https://doi.org/10.5271/sjweh.1470

7. Hernberg S. Towards a new millennium. Scand J Work Environ Health. 1999;25(6):465-9. https://doi.org/10.5271/sjweh.468

8. Burdorf A. Exposure assessment of risk factors for disorders of the back in occupational epidemiology. Scand J Work Environ Health. 1992;18(1):1-9. https://doi.org/10.5271/sjweh.1615

9. Burdorf A, Sorock G. Positive and negative evidence of risk factors for back disorders. Scand J Work Environ Health. 1997;23(4):24356. https://doi.org/10.5271/sjweh.217

10. Boggild H, Knutsson A. Shift work, risk factors and cardiovascular disease. Scand J Work Environ Health. 1999;25(2):85-99. https:// doi.org/10.5271/sjweh.410

11. Tossavainen K. Asbestos, asbestosis, and cancer: the Helsinki criteria for diagnosis and attribution. Scand J Work Environ Health. 1997;23(4):311-6. https://doi.org/10.5271/sjweh.226

12. Wolff H, Vehmas T, Oksa P, Rantanen J, Vainio H. Asbestos, asbestosis, and cancer, the Helsinki criteria for diagnosis and attribution 2014: recommendations. Scand J Work Environ Health. 2015;41(1):5-15. https://doi.org/10.5271/sjweh.3462

13. Härmä M, Kompier MA, Vahtera J. Work-related stress and health--risks, mechanisms and countermeasures. Scand J Work Environ Health. 2006;32(6):413-9. https://doi.org/10.5271/sjweh.1047

14. Härmä M, Kecklund G. Shift work and health - how to proceed? Scand J Work Environ Health. 2010;36(2):81-4. https://doi. org/10.5271/sjweh.2902

15. Stansfeld S, Candy B. Psychosocial work environment and mental health--a meta-analytic review. Scand J Work Environ Health. 2006;32(6):443-62. https://doi.org/10.5271/sjweh. 1050

16. Kivimäki M, Virtanen M, Elovainio M, Kouvonen A, Väänänen A, Vahtera J. Work stress in the etiology of coronary heart disease--a meta-analysis. Scand J Work Environ Health. 2006;32(6):431-42. https://doi.org/10.5271/sjweh.1049

17. Härmä M, Viikari-Juntura E. Development of the Scandinavian Journal of Work, Environment \& Health-the challenge of relevance, speed and accessibility. Scand J Work Environ Health. 2007;33(1):1-3. https://www.sjweh.fi/show_abstract.php?abstract_id=1058

18. Gilbert-Ouimet M, Trudel X, Brisson C, Milot A, Vezina M. Adverse effects of psychosocial work factors on blood pressure: systematic review of studies on demand-control-support and effort-reward imbalance models. Scand J Work Environ Health. 2014;40(2):109-32. https://doi.org/10.5271/sjweh.3390

19. Nielsen MB, Indregard AM, Overland S. Workplace bullying and sickness absence: a systematic review and meta-analysis of the research literature. Scand J Work Environ Health. 2016;42(5):359-70. https://doi.org/10.5271/sjweh.3579

20. Rugulies R, Aust B, Madsen IE. Effort-reward imbalance at work and risk of depressive disorders. A systematic review and meta-analysis of prospective cohort studies. Scand J Work Environ Health. 2017;43(4):294-306. https://doi.org/10.5271/sjweh.3632

21. Klingelschmidt J, Milner A, Khireddine-Medouni I, Witt K, Alexopoulos EC, Toivanen S, et al. Suicide among agricultural, forestry, and fishery workers: a systematic literature review and meta-analysis. Scand J Work Environ Health. 2018;44(1):3-15. https://doi org/10.5271/sjweh.3682 
22. Oakman J, Neupane S, Proper KI, Kinsman N, Nygard CH. Workplace interventions to improve work ability: A systematic review and meta-analysis of their effectiveness. Scand J Work Environ Health. 2018;44(2):134-46. https://doi.org/10.5271/sjweh.3685

23. Bannai A, Tamakoshi A. The association between long working hours and health: a systematic review of epidemiological evidence. Scand J Work Environ Health. 2014;40(1):5-18. https://doi.org/10.5271/sjweh.3388

24. Jørgersen JT, Karlsen S, Stayner L, Andersen J, Andersen ZJ. Shift work and overall and cause-specific mortality in the Danish nurse cohort. Scand J Work Environ Health. 2017;43(2):117-26. https://doi.org/10.5271/sjweh.3612

25. Vistisen HT, Garde AH, Frydenberg M, Christiansen P, Hansen AM, Andersen J, et al. Short-term effects of night shift work on breast cancer risk: a cohort study of payroll data. Scand J Work Environ Health. 2017;43(1):59-67. https://doi.org/10.5271/sjweh.3603

26. Torquati L, Mielke GI, Brown WJ, Kolbe-Alexander T. Shift work and the risk of cardiovascular disease. A systematic review and meta-analysis including dose-response relationship. Scand J Work Environ Health. 2017. https://doi.org/10.5271/sjweh.3700

27. Virtanen M, Jokela M, Madsen IE, Magnusson Hanson LL, Lallukka T, Nyberg ST, et al. Long working hours and depressive symptoms: systematic review and meta-analysis of published studies and unpublished individual participant data. Scand J Work Environ Health. 2018;44(3):239-50. https://doi.org/10.5271/sjweh.3712

28. Arends I, van der Klink JJ, van Rhenen W, de Boer MR, Bültmann U. Predictors of recurrent sickness absence among workers having returned to work after sickness absence due to common mental disorders. Scand J Work Environ Health. 2014;40(2):195-202. https:// doi.org/10.5271/sjweh.3384

29. Jakobsen MD, Sundstrup E, Brandt M, Jay K, Aagaard P, Andersen LL. Effect of workplace- versus home-based physical exercise on musculoskeletal pain among healthcare workers: a cluster randomized controlled trial. Scand J Work Environ Health. 2015;41(2):15363. https://doi.org/10.5271/sjweh.3479

30. Commissaris DA, Huysmans MA, Mathiassen SE, Srinivasan D, Koppes L, Hendriksen IJ. Interventions to reduce sedentary behavior and increase physical activity during productive work: a systematic review. Scand J Work Environ Health. 2016;42(3):181-91. https:// doi.org/10.5271/sjweh.3544

31. Reeuwijk KG, van Klaveren D, van Rijn RM, Burdorf A, Robroek SJ. The influence of poor health on competing exit routes from paid employment among older workers in 11 European countries. Scand J Work Environ Health. 2017;43(1):24-33. https://doi.org/10.5271/ sjweh.3601

32. van der Beek AJ, Dennerlein JT, Huysmans MA, Mathiassen SE, Burdorf A, van Mechelen W, et al. A research framework for the development and implementation of interventions preventing work-related musculoskeletal disorders. Scand J Work Environ Health. 2017;43(6):526-39. https://doi.org/10.5271/sjweh.3671

33. Schelvis RM, Oude Hengel KM, Burdorf A, Blatter BM, Strijk JE, van der Beek AJ. Evaluation of occupational health interventions using a randomized controlled trial: challenges and alternative research designs. Scand J Work Environ Health. 2015;41(5):491-503. https://doi.org/10.5271/sjweh.3505

34. Thiart H, Lehr D, Ebert DD, Berking M, Riper H. Log in and breathe out: internet-based recovery training for sleepless employees with work-related strain - results of a randomized controlled trial. Scand J Work Environ Health. 2015;41(2):164-74. https://doi.org/10.5271/ sjweh.3478

35. McInnes JA, Akram M, MacFarlane EM, Keegel T, Sim MR, Smith P. Association between high ambient temperature and acute workrelated injury: a case-crossover analysis using workers' compensation claims data. Scand J Work Environ Health. 2017;43(1):86-94. https://doi.org/10.5271/sjweh.3602

36. Burdorf A, Härmä M. The future of Scandinavian Journal of Work, Environment \& Health in the era of open science. Scand J Work Environ Health ;45(3):(213-4. https://doi.org/10.5271/sjweh.3826

\author{
Mikko Härmä, MD, PhD \\ Research Professor \\ Finnish Institute for Occupational Health \\ Helsinki \\ Finland \\ [Email: mikko.harma@ttl.fi]
}

